By RICHARD H. LOGSDON

\title{
National Library Week, 1959
}

$\mathrm{D}$ URING THE WEEK of April 12 through April 18, 1959, librarians of college and research libraries will have an opportunity to join in a nationwide effort to promote reading and the use of libraries. The achievements in 1958, the first year of the observance of National Library Week, were many and varied. National magazines alone carried twentytwo articles reaching a potential sixtyeight million readers. Newspapers published more than eleven thousand major stories within a three-week period. Radio and television coverage was similarly broad. At the state and local level, planning committees involved more than six thousand persons.

Even though there were many reported instances of participation by college and research libraries, the general feeling has persisted that these libraries as a group were somewhat under-represented among activities enjoying public notice in the 1958 celebration. None of the twenty-two articles in national magazines, for example, centered on academic libraries. There are, of course, times for caution, but it would seem that the overall objectives of National Library Week are so closely related to what college and research libraries are out to accomplish that we might safely venture, in larger numbers, to give it active support.

The celebration of National Library

Dr. Logsdon, Director of the Columbia University Libraries, is Chairman of the Association of College and Research Libraries Committee on National Library Week and a member of the Steering Committee for National Library Week.
Week is under the sponsorship of the National Book Committee in cooperation with the American Library Association. A central steering committee of nineteen persons carries responsibility for general planning, securing the necessary financial support, and guidance of a small headquarters staff. Committee members have been drawn from various types of libraries, from the publishing industry, from the field of communication, and from business and industry. John S. Robling, who headed the staff during the first year, continues as director for 1959. A distinctive feature of National Library Week is that it brings together into one program essentially all of the major agencies concerned with reading for information and education.

The organization for National Library Week is relatively simple, with the headquarters staff concentrating on the preparation of suitable poster and printed material; developing newspaper, magazine, radio, and television coverage of a national character; and advice and assistance to state committees. A key feature of the organization is the state directors and state committees appointed by the various state library associations.

The real success of the program will depend largely upon what is done by individual, public, school, and research libraries. Some two pages of ideas for colleges and universities are presented in the Organization Handbook for $\mathrm{Na}$ tional Library Week, reprints of which have been widely distributed. Copies may be secured from the New York office. ${ }^{1}$ Two distinct objectives are recognized for colleges and universities.

${ }^{2}$ National Library Week, 24 West 40 th Street, New 
One is "to make the institution's library and its resources better known to those who support it and to achieve a wider public understanding of its needs; the other is to encourage students' use of the library and reading beyond the formal requirements of the curriculum with the aim of developing lifetime reading habits." It is suggested that as a first step, the college librarian discuss the institution's participation in the state and local NLW program with the administration and the director of public relations as well as with the state director and any local committee. Cooperation with such other agencies as the college bookstore, the university press, and the college newspaper is recommended.

The main idea, however, is to encourage local initiative in developing whatever program will contribute most to the three principal objectives of $\mathrm{Na}$ tional Library Week: (1) a more understanding and effective support of libraries - school, college, and public; (2) a heightened sense of the importance of reading in national life; and (3) a more active enjoyment by people generally of the rich rewards of reading. Surely these are worthy of special attention by college and research libraries in concert with others during the week of April 12, 1959.

\section{Rare Book Meeting at Charlottesville}

A pre-conference meeting of rare book specialists is planned in connection with ALA's Washington Conference by ACRL's Rare Book Section. The meeting will be held at the University of Virginia, Charlottesville, June 18-20.

The program for the rare books conference is being planned by J. Terry Bender, chairman of the Rare Books Section; John Cook Wyllie, librarian of the University of Virginia; and William $H$. Runge, keeper of rare books in the University of Virginia Library. It will include a double series of programs emphasizing simultaneously procedures and problems of rare books, manuscripts, and special collections and a series emphasizing content values to be found in subjects relating to rare books and bibliographies. There will be a minimum of set speeches, and entertainment value is high on the list of criteria used in scheduling them.

Guided tours of the University's grounds will be available during the registration period on the afternoon of June 18, and a special tour to Monticello, the Jefferson home, is planned for the afternoon of June 20.

The registration fee for the entire session will be $\$ 30$. This sum includes board and lodging. Registrants will meet and eat in the University's new student union, Newcomb Hall. They will be housed in single rooms in a dormitory convenient to Newcomb Hall and to the Alderman Library. Librarians wishing to make their own living arrangements in Charlottesville will be charged $\$ 25$ as a registration fee.

Plans for the meeting are already well developed. It may be necessary, however, to cancel them unless there is a sufficient number of registrants for it. Details concerning registration and a deadline for it will be printed in the next $C R L$. A postcard now marked simply "Charlottesville" and giving your name and address will be taken as a tentative, but not binding, reservation and will help the committee in its planning. Address "Rare Books, ACRL, 50 East Huron Street, Chicago 11, Illinois." 